\title{
How the formation of one company led to many global optics clusters
}

\section{Bob Breault}

Bob Breault, "How the formation of one company led to many global optics clusters," Proc. SPIE 9664, Ninth International Topical Meeting on Education and Training in Optics and Photonics, 96642C (24 October 2005); doi: $10.1117 / 12.2207793$

SPIE Event: Ninth International Topical Meeting on Education and Training in Optics and Photonics, 2005, Marseille, France 
This paper is freely available as a resource for the optics and photonics education community.

\title{
Ref ETOP108
}

\section{How the Formation of One Company Led To Many Global Optics Clusters}

\author{
Bob Breault
}

\section{Abstract}

I took a circuitous, but planned route from a childhood of building small rockets (pre-Sputnik) in a small rural town, influenced by one keystone book on astronomy, received a BS in mathematics, but not to become a "mathematician", just to have it as a tool to do space based research. Then after graduation I planned on going into the Air Force as a fighter pilot, get to Luke Air Force base (the fighter pilot initial training school), Edwards Test Flight School, and Nellis Air Force Base as a "top gun" instructor. In this 1953 plan I would get a PhD from the University of Arizona at age 36 in astronomy designing and working on spacebased satellites and become an astronaut.

Take out going to Edwards Test Flight School, change the PhD in astronomy at age 36 to a $\mathrm{PhD}$ in Optics at age 38 analyzing many space based telescopes, include some academic challenges all along the way, add an invitation/request by NASA, immediately after receiving my $\mathrm{PhD}$, to reapply for the astronaut program (that I turned down by not re-applying), add the founding of Breault Research Organization, becoming a regional economic advisor to multiple regions in 29 countries and 18 states, and building 25 Optics Clusters around the world, and you have a synopsis of my life in bullet form. How, is the topic of the presentation?

\footnotetext{
${ }^{\text {i }}$ D. W. Johnson, R. T. Johnson, K. A. Smith, “A ctive Learning Cooperation in the College Classroom” Interaction Book Company, Edina, MN, 1991

ii -C. Poyatos, C. Allan, "The use of learning portfolios to devdop generic skills: An evaluative case study with on-line Industrial Rdations students", ETL Conference, 2003, Queensland College of Art, Griffith University -Classroom A ssessment Tedhniques Portfdios. http://www.flaguide.org/cat/portfolios/portfolios1.php

iii-Electronic Portfolios in Teacher Education. Carla Hagen Piper. http:/ / www. dhapman.edu/soe/ faculty/piper/EPWeb/tochtml

iv - Queensland University of Tedhndogy. http:/ / www.studentportfdio.qut.edu.au/overview/ -The Kalamazoo College Portfdio- http:/ / www.kzooedu/pfolio/ -Dr. Helen Barrett, http:// dectroniqportfdios.org
}

v J. Walker, J. Briggs, A. Gibbons, G. Putnam, T. Nally, and B. Shoop, "Optics Education-A Blueprint for the $21^{\text {st }}$ Century", Proceedings of the SPIE: Education and Training in Optics and Photonics, T. Lim and A. Guenther, Editors, Vol. 4588, 2002.

${ }^{v i}$ S. M. Pompea and I. Hawkins, "Increasing Science Literacy in Optics and Photonics through Science Centers, Museums, and Web-based Exhibits", Proceedings of the SPIE: Education and Training in Optics and Photonics, T. Lim and A. Guenther, Editors, Vol. 4588, 2002.

vii S. M. Pompea and T. K. Gek, "Optics in the Great Exploration in Math and Science (GEMS) Program: A Summary of Effective Pedagogical Approaches", Proceedings of the SPIE: Education and Training in Optics and Photonics, T. Lim and A. Guenther, Editors, Vol. 4588, 2002

${ }^{\text {viii }}$ M. Hall-Wallace, N. L. Regens, and S. M. Pompea, "Design of a Professional Development and Support Program for Future Photonics Industry Team Leaders", Proceedings of the SPIE: Education and Training in Optics and Photonics, T. Lim and A. Guenther, Editors, Vol. 4588, 2002.

ix S. M. Pompea and Alan Gould, Invisible Universe: The Electromagnetic Spectrum from Radio Waves to Gamma Rays, Book in the Great Explorations in Math and Science (GEMS) Series, Lawrence Hall of Science, Berkeley, CA, 2003. 